\title{
Life, Time, and the Organism: Temporal Registers in the Construction of Life Forms
}

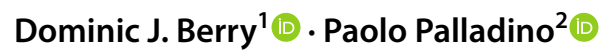

Published online: 30 October 2018

(C) The Author(s) 2018

\begin{abstract}
In this paper we articulate how time and temporalities are involved in the making of living things. For these purposes, we draw on an instructive episode concerning Norfolk Horn sheep. We attend to historical debates over the nature of the breed, whether it is extinct or not, and whether presently living exemplars are faithful copies of those that came before. We argue that there are features to these debates that are important to understanding contemporary configurations of life, time, and the organism, especially as these are articulated within the field of synthetic biology. In particular, we highlight how organisms are configured within different material and semiotic assemblages that are always structured temporally. While we identify three distinct structures, namely the historical, phyletic, and molecular registers, we do not regard the list as exhaustive. We also highlight how these structures are related to the care and value invested in the organisms at issue. Finally, because we are interested ultimately in ways of producing time, our subject matter requires us to think about historiographical practice reflexively. This draws us into dialogue with other scholars interested in time, not just historians, but also philosophers and sociologists, and into conversations with them about time as always multiple and never an inert background.
\end{abstract}

Keywords Breeding $\cdot$ Organism $\cdot$ Synthetic biology $\cdot$ Time $\cdot$ Value

Dominic J. Berry

d.j.berry@1se.ac.uk

Paolo Palladino

p.s.a.palladino@rug.nl

1 University of Edinburgh, Edinburgh, UK

2 University of Groningen, Groningen, The Netherlands 


\section{Introduction}

The Norfolk Horn Breeders' Group (NHBG) aims to "advance awareness, promotion, preservation and enhancement" of the ovine breed in its care. In a short historical sketch, the NHBG (2012) reports that the Norfolk Horn breed had been important to the medieval worsted industry, as well as to the maintenance of four-course rotation across East Anglia, an agriculturally prosperous region in south-eastern England. From the late eighteenth century, however, as greater attention was paid to the improvement of livestock, renowned agricultural improvers dismissed the breed as worthless and promoted its replacement with the Southdown. The crossing of any remaining Norfolk Horn with the Southdown resulted ultimately in the creation of the Suffolk, which has proven invaluable to modern farming. As a result, the number of Norfolk Horn plummeted down to a single flock, which, in the early twentieth century, was placed under the care of the Animal Research Station at the University of Cambridge as the object of studies into the inheritance of an organic disorder said to characterize inbred animals. By the late 1960s, the Norfolk Horn was on the brink of extinction, but, according to the NHBG, the Rare Breed Survival Trust (RBST) has brought the Norfolk Horn back from the brink.

The narrative is compelling. At the same time, however, a recent history of sheep and the British landscape (Walling 2014) reports that:

Joe Henson ..., Michael Rosenberg and Lawrence Alderson were founder members of the RBST and took the lead in re-creating a simulacrum of the Norfolk, the Norfolk Horn, from the cross-bred lambs out of the Suffolk. It is from these that the new Norfolk Horn is descended. This is not the same contemptible animal that Coke affected to despise, but a tamer version of the old indomitable breed (154-5) (emphasis added).

Walling is not the only author to question whether the original Norfolk Horn and its contemporary representatives are equally worthy and of the same breed, see for instance Wade-Martins (1993).

In the Norfolk Horn we find an organism and breed whose status as ancient or novel, natural or artificial, worthless or valuable, is uncertain. Bombarded as we presently are by claims to the novelty, productive potential, and economic value of the most disparate biological objects and systems, the Norfolk Horn becomes an ideal focus of attention. For the sake of brevity, our discussion of its importance emerges from a protracted discussion about genes, organisms, and the writing of history (Palladino 2003; Berry 2014a, b). One of us, in the course of their work on bio-heritage and the renewal of rural economies, discovered a number of provocative debates about rare breeds such as the Norfolk Horn. ${ }^{1}$ The other noted features of these debates that echoed discussions of synthetic biology and its future development. While the resulting investigation of the resonance allows us to cast

\footnotetext{
1 This paper was made possible by Palladino's tenure of a fellowship to study the relationship between sheep, wool, rural regeneration and connectivity in British, Spanish and Italian uplands, and by Berry's participation in a European Research Council project on engineering life.
} 
unexpected light on these latter discussions, the overall emerging understanding of the relationship between life, time, and the organism is important to the biological sciences more generally.

The proposed resonance between animal breeding and synthetic biology becomes particularly evident when we turn to the first issues of Ark, now the official organ of the RBST. ${ }^{2}$ In the very first issue, the editors reported that the Norfolk Horn no longer existed, but its blood-line had survived and this could serve to re-establish the breed. Two years later, the editors introduced a forum in which selected figures within the newly established RBST would discuss issues of interest to its members. The first of these discussions was again dedicated to the Norfolk Horn, asking whether and how the investment of the resources required to re-establish the breed might be justified:

How can the Trust justify expending its resources on breeding-back programmes, such as the New Norfolk Horn project, when the final product can never be a pure breed and will only approximate in its characteristics to the original, but now extinct, breed? (Ark 1976, p. 54).

The responses elicited evoke diverse notions of originality. ${ }^{3}$

James Hindson, a veterinarian, sought to distinguish recreation and reconstruction, deeming the former impossible and the latter desirable, primarily because it was important to remember the Norfolk Horn and its contribution to the making of modern agriculture. Michael Rosenberg and Andrew Sheppy, two commercial breeders, operated with a different notion of originality. Specifically, Rosenberg responded by arguing that any distinction between recreation and reconstruction could only be qualitative. From a quantitative perspective, any categorical distinction was untenable because, as a result of outcrossing in the field and on the farm, no breed is ever completely and unambiguously differentiated from any other. Sheppy echoed Rosenberg, adding that the rarity of a breed referred to its contemporary numbers, not its history. From Sheppy and Rosenberg's perspective, the Norfolk Horn was to be defined in relation to a genealogical lineage and what mattered most was the proper management of biological reproduction and its vagaries. Finally, Lawrence Alderson, scientific advisor to the RBST, observed that decisions in the matter discussed should be based on whether or not the attained animals would repay an imagined, future farmer's attention. ${ }^{4}$ Furthermore, if what was desired was a sheep exhibiting the original breed's distinctive features, these could be obtained

\footnotetext{
${ }^{2}$ For a history of the RBST, see Alderson and Porter (1994). The broader social context out of which the RBST emerged is examined very usefully in Evans and Yarwood (2000).

3 Determining who was involved in the debate is not easy. Andrew Sheppy, for example, was not one of the invited participants and intervened by writing a letter to the editors; see Sheppy (1976). Woods (2013) also suggests that Peter Jewell's (1975) contemporaneous, more general case for the preservation of domestic livestock should be regarded as contributing to the discussion.

4 Alderson, who also owned and edited the journal, wrote under a pseudonym, George Hastings; interview with Lawrence Alderson (on 8 March 2016). The creation of the forum in which the debate took place also served as a marketing device to attract readers' attention to the issues covered in the new journal and the new enterprise that was the RBST.
} 
most readily by drawing on alternative and unrelated breeds, rather than committing to a program based on genealogical relationship. Here, originality was evacuated of all reference to historical processes and genealogical descent, and was understood instead as the match between contemporary exemplar and intended design.

The question of whether the Norfolk Horn is extinct or not is one that was, and still is, divisive, but the discussions on the pages of Ark suggest that the answers will depend on one's definitions and starting assumptions about authenticity and artificiality. This understanding applies just as well with regard to the discussions about synthetic biology and its proposals to bring equally iconic animals back from extinction, and to the more general questions about the relationship between copies, originals, and simulacra which synthetic biology raises, as it sets out to transform organisms into the wholly disciplined materials of engineering and industrial manufacture. ${ }^{5}$ In what follows we build on such resonance by first observing how the diverse views on the relationship between copies and original at stake in the debates over the Norfolk Horn would seem to entail three equally distinct temporal registers, which, for reasons we outline below, we will label historical, phyletic, and molecular. In so doing, we adopt and advance the notion that time is best understood as the product of social and cultural practices that also contribute to the moral and economic valuation of the objects involved. Secondly, there is a potential difficulty related to the organic nature of the objects on which we focus. Does it matter that the understanding of time which we advance rests on the construction of living rather than non-living things? If we were to take synthetic biology as our guide, our focus on living or once living organisms introduces no difference at all. For synthetic biologists, and for some of those who study them, the organism, like any other manufactured material, is devoid of any intrinsic temporality and the aim of the enterprise is to overcome the "tyranny" of evolution (Endy, as quoted in Frow 2013, p. 443). By contrast, what we find while attending to the Norfolk Horn is something quite different. Not only are organisms clearly situated in time, but the temporal registers involved are multiple, binding the organism, life, and time in unexpectedly complex ways. The registers' mutually constitutive relationship to one another suggests that synthetic biology's denial of time is part and parcel of the same phenomenon, the plurality of ways in which time contributes to the construction of relationships between life and the organism. We conclude therefore that the organism's existence in time might then be best characterized as a plural form of existence, such that "biological time" must give way to "biological times."

In sum, ours is a history of the present, intent on demonstrating why and how the multiple temporalities emerging from the Norfolk Horn story matter today. There may be a still more important payoff for the community of historians of biology. We are a community most at home writing, enriching, and exploring the historical register, here and there noting and exploring the phyletic and molecular, though ultimately in ways that result in making the historical more valuable and authentic.

\footnotetext{
5 The literature on synthetic biology emerging from science and technology studies is extensive. Starting points include Balmer et al. (2014), Ginsberg et al. (2014) and Scott et al. (2018). See also Campos (2010) and Fox Keller (2009) for two influential historical treatments.
} 
There is a disorientation that follows upon noticing the operation of temporal registers, one that we seek to cultivate. We hope that as soon as you have finished reading, you will feel the need to rush out, stare at a sheep and repeatedly ask yourself "what is this now?"6

\section{Concepts and Methods}

In what follows, we articulate the features and functions of three temporal registers, registers being our preferred term for the temporal component of material and semiotic assemblages. We label the first of these historical because it focuses on the commemoration of the past, and the second phyletic because it is concerned with lines of descent. Borrowing Deleuzian terminology, we label the third and final register molecular, to capture how entirely different phyla might be imagined if one were to focus on elementary parts, rather than organisms and lineages. As Deleuze and Guattari (1988) put it with regard to Geoffroy Sainte-Hilaire's understanding of organic forms and their temporal organization,

Organic forms are ... different from one another, as are organs, compound substances, and molecules. It is of little or no importance that Geoffroy chose anatomical elements as the substantial units rather than protein and nucleic acid radicals. At any rate, he already invoked a whole interplay of molecules. The important thing is the principle of simultaneous unity and variety of the stratum (46).

The molecular register, as we shall see, organizes things differently from either the historical or the phyletic. There will of course be other important readings of our terminology, but we wish to be clear that we are not presuming some all-embracing molecular science. In fact, the various biological enterprises that today operate at the molecular scale might make for very interesting sites in which to search for different temporal registers, no doubt beyond the three proposed here; see also (Marks 2006). ${ }^{7}$

We draw particular attention to our registers' following three features. First, and perhaps restating the obvious, the registers are more than one. Elements of such pluralism have already been advanced elsewhere. Thus, Shavit and

\footnotetext{
${ }^{6}$ One of our reviewers noted the resonance between our argument and Deleuzian perspectives on copies, originals, and simulacra, asking why we did not refer to Deleuze's Difference and Repetition (2004). As we explain below, we regard this as the kind of ontological purification that we wish to resist, not because we are sceptical about the accounts that sustain the argument, but because we see no need for any commitment to a differential ontology and so prefer agnosticism.

7 In an earlier draft we had called the register "phylogenetic," knowing that some biologists and philosophers might regard this as misappropriation. A very persuasive reviewer pointed out the variety of ways in which the term has been used in different branches of biological science, offering the examples of systematics and developmental biology, and that these uses often are inconsistent with the distinctions we here build between temporal registers. We hope that "molecular" avoids these problems, without masking our intentions or overemphasizing the importance of substances such as DNA. We would like to thank this reviewer for their fulsome engagement with our argument.
} 
Griesemer (2009) have sought to examine whether and how ecologists are able to return to the same research site, much as we are interested in what it might mean to reproduce the same organism. In doing so, they characterize the multiple conceptions of space at work in pivotal ecological practices and the problems that they generate for any understanding of biodiversity. An interesting difference between their argument and the one developed here is, however, that we do not aim to clarify the conceptions of time mobilized in the diverse contexts we examine. Rather than considering their role as guides in the clarification of epistemic practices, we emphasise a number of functions that these diverse conceptions of time fulfil, some of which might be called social or cultural, others epistemic, and aim to show how multiple temporalities are at work within the same organism. In this last respect, our approach is closer to those cultural geographers who have drawn attention to the many temporal registers that are involved in the construction of place; see (Crang 2001). Second, these registers do not exist independently of one another, but are instead involved in each other's construction. To put the point simply, we argue that when our actors point to the historical significance of the Norfolk Horn, they also draw on phyletic and molecular understandings of the Norfolk Horn, even as they differentiate the three temporal configurations of the Norfolk Horn from one another. In so doing, we again echo Shavit and Griesemer's own understanding, when they argue that "each mode of study inextricably figures in the other" (p. 275). Third, we show that it is the resulting complex relationship between the different registers that establishes the worth of the objects at issue. This may be of some importance not only to understanding the complex relationship between contemporary investments in rare breeds and place, but also to the more general investments of care for the lives of the organism (Colombino and Giaccaria 2015, 2016; Shukin 2009).

Having drawn on the debates over the Norfolk Horn to characterize our three registers, we will then bring the resulting understanding of time and the organism to bear on contemporary endeavours that are related very poignantly to the fate of the Norfolk Horn. Just as an earlier generation of breeders sought to advance their position by bringing the Norfolk Horn back from the verge of extinction, so today some synthetic biologists are advancing their position by claiming that they can, for instance, bring the famed wooly mammoth back to life (Church and Regis 2012; ETC Group 2013). Just as synthetic biologists derive power from undoing the work of historical time, so did those debating how to secure the Norfolk Horn's continued existence. Just as the manipulation and capacity to reconstitute organisms outside the constraints of phyletic lineage today excites synthetic biologists and their audience, so too did such claims excite those invested in the power of breeding to transform organisms. While the parallels are inescapable, however, ours is not a comparative exercise, not least because the label "synthetic biology" covers a multitude of very different and distinct research programmes and activities that makes for an unsuitable mirror for the very particular goal of reviving a breed. We argue instead that the play of temporal registers that is involved in debates over the nature of the Norfolk Horn helps us to understand how these synthetic biologists and other allied actors extract value from their work. It helps to understand how the process of creating value within synthetic biology involves the mobilisation of multiple temporal 
configurations of the organism, even as it positions some organisms outside time; see also (Dussauge et al. 2015).

Methodologically, our mode of inquiry into the significance of the Norfolk Horn is genealogical (Foucault 1977). We have adopted this mode because we are interested in understanding the production of the present as the welding together of disparate material and semiotic resources, particularly as they relate to temporal configurations of the organism. In this context, relationships between the present and the past are so complex that we find ourselves not only returning to older discussions regarding the role of the historian in reconstructing the past, but also asking what forms of life historians bring into the present through their reconstructions of past relations to organisms, either dead or alive; see (Lowenthal 1998, 2005). Classic texts such as Clarke and Fujimura's The Right Tools for the Job (1992) call for closer, critical inspection of the kinds of organism that these accounts stabilise; see also (Latour 1986; Law 1986). We are drawn to the greater detachment that genealogical method would seem to afford. Such attraction is also a response to those philosophers who have turned to the organism in order to overcome the limitations of existing, universalising schemes, including the historical. Primarily we have in mind Heidegger and Deleuze's different responses to Nietzsche's iconoclastic embrace of evolutionary process and its evacuation of the natural world of all meaning (Buchanan 2008; Storey 2015). While Heidegger sought to ground the reconstruction of philosophy in the mortality of the organism, particularly that of the human organism, the latter sought to ground the same reconstruction by reframing the understanding of evolutionary process as an endless production of difference, a reframing in which the organism and its mortality ceased to enjoy any privilege. As Deleuze and Guattari (1988) once put it, with respect to the proliferative powers of life itself, "the enemy is the organism" (p. 158); see also (Colebrook 2011; Protevi 2012). There is a considerable overlap between this understanding of organic existence and the ambitions of synthetic biologists, for whom studied indifference about the organism is a founding assumption and to such extent that Calvert reports on their speaking of "organism agnosticism" (Calvert, in draft; Johnson 2010). In sum, the diverse understandings of life, time, and the organism on which these divergent historical and philosophical perspectives rest mean that no temporal frame can be taken for granted, making the genealogical urge to question the nature of the present seem particularly well suited (Dean 1994; Hoy 2008).

Finally, our paper could also be regarded as contributing to ongoing debates regarding the ontological turn within science and technology studies (van Heur et al. 2012). Firstly, insofar as we attend to the circulation of a common object within a divided community and its role in the production of value, we contribute to the literature on the subject (Dussauge et al. 2015). At the same time, our understanding of the relationship between the competing groups is closer to Luc Boltanski and Laurent Thévenot's (2006) pluralist perspective on social action, and is also indebted to Michel Serres' (2007) connected insight that the work of mutual definition that is involved in relational modes of existence creates yet other relationships (Brown 2002; Guggenheim and Potthast 2012). As a result, our understanding of circulation is more open than the literature on material culture and the production of value will admit and to the extent that we can imagine how the dynamics we outline might 
produce temporal registers beyond the three considered here. Secondly, we have been asked whether we are discussing plural temporalities or just the many ways in which time is cast. Consistently with our turn to Boltanski and Thévenot, our answer is that this depends on our readers. If they are committed to the view that only one kind of time has persisted throughout cultures and over ages, then we are committed to keeping open the possibility that there may be many times. We regard it as the job of the ontologist to uncover which is true and which false, though we fear that no closure is possible. If, alternatively, our readers are comfortable with the suggestion that there may indeed be many kinds of time, then for the purposes of this paper we can set ontological assumptions aside and treat the registers in this paper as capturing the different ways in which time can be framed or understood and the effects of that framing. As a result of these two sets of considerations, pluralist and pragmatist, we embrace the proliferating complexities of the phenomenal world, particularly as this relates to contemporary development of science and technology, but also remain unpersuaded by the urge to weld the resulting multiplicity together and forge a common world (Mol 2002; Law 2004, pp. 45-67). We thus find ourselves very sympathetic toward Lynch's (2013) call to ontography, to "ethnographic investigations of particular world-making and world-sustaining practices that do not begin by assuming a general picture of the world" (p. 444). At the same time, we cannot but be wary of Lynch's further call to historical investigation.

We now proceed to articulate these temporal registers in greater detail, aiming ultimately to draw out their complex, mutually constitutive relationship to one another.

\section{The Historical Register}

It is deceptively easy to characterise the historical register because, on the surface, it is the register with which most of us are intuitively familiar. Yet, such familiarity might lead too readily to labelling everything that is written of things from the past, or informed by an understanding of what came before, as a history. As we shall see with the phyletic and molecular, however, there are ways of understanding objects of the past in relation to the present that are not necessarily historical. The Norfolk Horn helps us to explain.

As the arguments over the preservation of the Norfolk Horn began to take shape, Ark acknowledged its debt to Frank Rayns, former director of the Norfolk Agricultural Station, by reprinting Rayns' history of the breed, which had been first published some years earlier, in the Journal of the Royal Agricultural Society of England (Rayns 1975).

Rayns' central claim was that the Norfolk Horn's disappearance was important to any understanding of the British agricultural revolution, the transformation of the agricultural economy and related modes of production that unfolded over the course of the 18th and 19th centuries (Overton 1996). Prior to the late 18th century, when the term "Norfolks" was first employed, there were no precise descriptions of the many sheep that sustained the mixed farming economy of East Anglia. When these same sheep eventually came to the attention of some of the most famous agricultural 
improvers of the period, their connotations were overwhelmingly negative. Thus, in 1808, Thomas Coke reminded local dignitaries of their duty to "eradicat[e] the Norfolk breed of sheep, the most worthless race of animals that ever existed" (WadeMartins 1993, pp. 34-35). No lesser figures than Arthur Young, William Marshall and David Low, leading agricultural writers of the day, took note of the transformation in which these sheep were caught up, and, as early as in 1842, Low was persuaded that they were destined for extinction. He wrote:

While [the Norfolk] might still have retained its property of hardiness and robustness, the too great length of the limbs, the flatness and lankness of the body, and, with the change of external form, the too great wildness of temper, might have been corrected, as is the case of every other race of Sheep to which the care of the breeder has been directed. But few breeders appear to have thought the Norfolk so deserving of preservation and improvement, as to have deemed it necessary to apply to it those principles of breeding which have been successfully applied to other races. Very lately, indeed, the matter has occupied the attention of the possessors of the few unmixed flocks which remain; but unless these gentlemen are seconded by more extensive support than they have yet received, it is believed that this ancient race will, at no distant time, be merged in others which have acquired a higher value by the care of the breeder (Wade-Martins 1993, pp. 63-64).

Leading historical accounts of the period corroborate this understanding. In a classic analysis of Victorian society, Ritvo (1987) observes how an animal came to be regarded as good only insofar as it took to its place in the environmental landscape in a way that exemplified God's intended ordering of nature. The most noble were those animals domesticated and bred to directly serve human purposes. On this understanding, the Norfolk sheep were failures many times over, first as one of those old strains developed as a result of random mating and the accidents of time and place, second thanks to their wild temper and liability to jump over the quintessential symbol of agricultural improvement, the enclosing wall, and third, because the landscape to which one might have thought they fitted most perfectly was actually being enclosed all around them. What was desired was a wholly different sheep. Southdown and Leicester sheep were crossed with the native sheep of Norfolk, eventually resulting in the creation of the Suffolk and its correlative association of farmers and breeders, the Suffolk Sheep Society. While the Suffolk was the desired end of agricultural improvement in East Anglia, the "Norfolk Horn" also emerges as a result of this process, but not so much as a distinct breed, rather as an unclaimed population much more akin to a landrace, and valued primarily for its role in the creation and perpetuation of the Suffolk.

In sum, according to the terms the historical register sets, if anything like a Norfolk Horn exists today, it does so as a testament to the culture of improvement, but also as an artefact very much out of time. One wonders about the extent to which the insistence on the continued existence of something whose context has so demonstrably disappeared can be regarded as anything other than romantic attachment, but the tension has long bedevilled the relationship between history and heritage, and, if 
anything, this situation calls for some consideration of what may be distinctive about "bio-heritage" (Lowenthal 1998, 2005).

\section{The Phyletic Register}

In its historical framing, the Norfolk Horn, a neglected, chastised, and accidentally engendered breed eventually became extinct, and all that remains are memories, material and immaterial. This understanding, however, runs counter to an alternative temporal configuration of the Norfolk Horn, the phyletic register. This is the mode of reasoning about the temporal configuration of organisms that Ritvo (1987) takes as her object of study, but which can also be considered more symmetrically than the historian is want to, or can do.

The first thing to note about the historical register is that an important tension runs through its framing of the Norfolk Horn. On the one hand, it regards the Norfolk Horn as something like a gift of nature, so much so that it was long regarded as "formed more like deer than sheep... deer-like sheep" (Culley 1786, p. 121). On the other hand, it also regards the loss of the Norfolk Horn as the inevitable price the progress of agriculture has exacted. The historical register, in other words, presumes an original object of care that is lost in the passage of time. Within the phyletic register, however, this relationship to the passage of time makes little sense because what makes sheep what they are is not some essential feature, imprinted at their origin, but their line of descent. Organisms are constantly undergoing change and transformation, be it through the vagaries of reproduction or through farmers' and breeders' studied interventions, be they in the form of selective culling or selective mating. The extent to which the Norfolk Horn ever existed was therefore only the extent to which these farmers and breeders agreed that a given flock conformed to the standards of the day, eventually institutionalized by breed societies (Ritvo 1987; Woods 2013, 2017). As an adjectival qualification, phyletic signals this distinctive social and cultural investment in understanding the relationship between present and temporally removed sheep in terms of a lineage, or a phylum (Franklin 2007; Strathern 1992).

On the terms that the phyletic register sets, preservation is a matter of negotiating the features which make for a true Norfolk Horn and the survival of enough sheep to maintain a healthy population. Here is where extinction emerges as an issue within the phyletic register. Not enough breeders found a way to make the maintenance of the Norfolk Horn pay. Once really valuable sheep such as the Suffolk were well established, these breeders no longer cared to keep any flocks of Norfolk Horn and so the breed died out.

In sum, within the phyletic register, extinction is a matter of consensus between breeders. If we were to abide only by the social and cultural practices that constitute animal breeding, the proposition that the Norfolk Horn was extinguished would be near impossible to avoid. The only way to prevent all breeders from agreeing with this proposition is to appeal to a third temporal register, the molecular. As we shall see, the molecular could not be more different from the phyletic. Later we explain 
how nevertheless making the molecular appear compatible with the phyletic is all part of the value making that temporal registers achieve.

\section{The Molecular Register}

The RBST eventually agreed that there was no need to distinguish between old and new representatives of the Norfolk Horn, nevertheless, as we have seen, doubts continue to be voiced to this day. Perhaps unsurprisingly, the historian Peter Wade-Martins is one such skeptic. He writes:

We have lost "the great length of the limbs, the flatness and lankness of the body" and "the great wildness of temper" so aptly described by David Low in his Domesticated Animals of Great Britain published in 1842. The docile nature and conformation of the present-day breed carries many of the characteristics of the placid Suffolk, which in turn derives its docility from the Southdown. The modern Norfolk is not the agile "deer-like" animal early writers frequently described. ... Today's Norfolk is, however, the closest we can now come to the genes of this once primitive breed (Wade-Martins 1993, pp. 172-173).

Strikingly, this historical and nostalgic evocation of the Norfolk Horn closes by referring not to the sheep themselves, but to genes. This is the stuff of the molecular register.

In the potted history with which we began, as the number of Norfolk Horn plummeted down to a single flock, it found a home in the Animal Research Station (ARS) at the University of Cambridge, as the object of studies into the inheritance of an organic disorder that was understood to characterize inbred livestock. This claim is particularly important for differentiating the phyletic and molecular temporal registers.

In the course of the debates over the Norfolk Horn, Ark reprinted a report first published thirty years earlier (Ark 1984). This report could be read as suggesting that the interest in the breed within the ARS revolved primarily around the failure of testicles to descend and its impact on the reproduction of the flocks to which a ram was put. As such, we could conclude that a phyletic perspective framed the ARS's investment in housing the Norfolk Horn. From a molecular perspective, however, the important point is that the continued transmission of the trait from one generation to the next illustrated the failure to appreciate how organisms are genetic composites that are easily undone by careless practice, witness the precarious state of the flock that the ARS housed. As Peter Jewell (1993) observed in the foreword to Wade-Martins' history: "It is alarming to know how close [the Norfolk Horns] came to extinction, but also exasperating to learn how often they were nearly saved intact. ... John Hammond [Director of the ARS] ... failed to appreciate their breeding plight. In truth, he was probably more interested in their prevalent condition in which the rams had only one descended testicle, than in the survival of the breed" (xv). Extinction was only averted once the RBST transformed local understanding of the Norfolk Horn's cryptorchidism into a symptom of inbreeding, replacing the 
practice with a balanced programme of inbreeding and outbreeding. This, so it goes, eventually enabled the RBST to revive a lineage and improve the commercial position of the Norfolk Horn, by re-establishing the breed and to a level of purity above the usual standards.

As Alastair Dymond put it just prior to the official agreement that there was no difference between the old and new Norfolk Horn, the recovery was a business of reshuffling genes to match the desires of the day: "This was not the reconstruction of a breed but the consolidation of existing genes to enable the breed in the future to claim "pure" status or certainly as pure as many of the "pedigree" breeds in existence today" (Dymond 1982, p. 7). The temporal frame here is not oriented toward either the past or any lines of descent, but to the future, to the recombinatory space of possibilities opened up by crossing different breeds. One might even propose that the molecular register jettisons all attachment to the past, except perhaps that the value of bringing the Norfolk Horn back from extinction stems from the past.

\section{Time and the Creation of Value}

As we noted at the outset, the three temporal registers depend on one another and such dependence is key to the creation of value. We now draw out the full complexity of such relations.

It goes without saying that the extinction of the Norfolk Horn and investment in its contemporary copy are central to the historical temporal register, so driving the enterprises of reconstruction. ${ }^{8}$ The phyletic register emphasizes, however, how all populations are forever undergoing change. If sheep are artefacts exhibiting a breeder's selective prowess in the face of change, then the Norfolk Horn should emphatically have gone extinct. That was the correct order of things. At the same time, despite their differences, the phyletic register also depends upon the existence of something like the historical Norfolk Horn. To a farmer tending to flocks of a similar size and carrying out similar daily tasks with respect to more or less similar organisms, there is little practical difference between them all, but, occasionally, some are regarded as more valuable than others. On this particular occasion, the reason to invest in one population of sheep rather than another was the history of the Norfolk Horn. In sum, the maintenance of breeds such as the Norfolk Horn, an activity composed in the phyletic register, is justified by and at the same time antagonistic to the historical register.

In a similar fashion, the molecular register owes its resonance to the historical register because, as Wade-Martins has it, genes are witnesses to processes of historical transformation and so they also are key to the recovery of that which was thought lost. Again, however, the molecular is simultaneously antithetical to the historical register because the passage of time leaves the genes themselves unaffected. If so desired, all the meanings and values attached to the Norfolk Horn in the historical

\footnotetext{
${ }^{8}$ Franklin (2007) traces how such historical investment is translated into the economic value attached to transgenic reproduction.
} 
register can be brushed aside. Equally, the molecular register is produced in part by the phyletic because genes are shuttled around in organisms whose taxonomic grouping and genealogical ordering were important to deciding what crosses were most desirable to recover the Norfolk Horn, and yet it also is antithetical because the genes required could have been obtained with equal ease from sources that the phyletic framing of the organism would rule out.

Importantly, the relationship between these temporal configurations is not only conceptual, but also rooted socially and economically. Firstly, Walling's understanding of the contemporary Norfolk Horn as a "simulacrum" points to a wellestablished notion of the copy as derivative and inferior to the original, and thus to the transformation of the lost original into a highly desirable object. Secondly, if breeders once exterminated the Norfolk Horn because they were of no economic value, breeders and geneticists today work in the image of historical reconstruction, increasing differentiation between all animals that already exist and providing means for new economic valuations, including the importance attached today to heritage breeds (Yarwood and Evans 2006; Colombino and Giaccaria 2015). Thirdly, from the geneticist's perspective, the phyletic register leaves open and indeterminate how best to shape the response to the new economic opportunities just mentioned. For example, Sheppy (1979), as a commercial breeder, insisted on the importance of outbreeding with distantly related breeds because only such distance would enable the breeder to visualize the manifold and not always predictable effects of the crosses undertaken. As the trained geneticist, Alderson (1982) sought to narrow the scope for judgment and fortune by advancing an understanding of sheep as genetic assemblages that were amenable to recomposition by means of the calculated movement of rams between different flocks. As such, what also divided Sheppy and Alderson were the competing professional priorities and technical capacities of breeders and geneticists, as well as the relationship between breed societies and a new generation of commercial breeders, steeped in the language of genetic science (Holloway and Morris 2012). From the latter's perspective, anything could be had. If "deer-like" agility were desirable and valuable, the appropriate genes could be found to produce an even more authentic Norfolk Horn, but at some financial cost. In other words, if, as the NHBG and RBST argue, the original Norfolk Horn came extremely close to being lost, it has at the same time been almost miraculously preserved, thereby adding maximum economic value to the contemporary representatives of the Norfolk Horn. As such, distinctions between geneticists' and breeders' practices of improvement as dependent on more or less explicit forms of knowledge, as well as the characterisation of the latter's "tacit" skills as "traditional," needs to be treated with circumspection, because this terminology is not neutral, but the product of the struggle between breeders and geneticists for authority and pre-eminence over a shared agonistic field (cf. Holloway and Morris 2012; Boltanski and Thévenot 2006). ${ }^{9}$

\footnotetext{
9 In their very helpful analysis of breeders' and geneticists' practices, Holloway and Morris (2012) draw out their co-constitutive relationship. At the same time, however, they also configure the two assemblages as the product of a single governmental formation. From our perspective, this assumption reduces the scope for any understanding of the relationship between breeders' and geneticists' practices, including their temporal configurations of the organism, as open-ended.
} 


\section{Synthetic Biology and Its Times}

We now turn our attention to how the organism, as a material and semiotic assemblage, may today be undergoing a further transformation, one which can be understood better thanks to the apparatus of temporal registers.

A group of scientists and engineers collected together under the umbrella of synthetic biology claim to be transforming biological existence. They sometimes do so in ways that resonate with the molecular register. The pivotal notion that organisms can be decomposed and recomposed by attending to DNA and its cellular functions, for instance, is no different to Alderson's understanding of breeding and its future. Furthermore, time is equally important to both parties' endeavour to establish the value of their expertise. There is, however, one clear difference between what is going on within synthetic biology and the molecular register. Synthetic biologists argue that organisms are no longer needed to perpetuate a lineage because machines can now produce whatever DNA sequence is desired, be it a copy of a sequence found in nature or something that has been designed to meet human specifications. Perhaps unsurprisingly, leading figures in the field have come to regard evolution as a historical process imposed upon biological form, positioning synthetic biology as liberating the organism from such tyranny (Endy 2014).

Frow (2013) summarizes the situation very usefully, pointing to the distinctive temporal structure of synthetic biology:

Through practices of isolation, measurement, standardization and reconfiguration, these biological parts become dissociated from their species provenance and evolutionary histories. A key aim of these efforts is to disentangle genetic material from its biological context so as to facilitate the flow of genetic information across space, time and organisms, to enable entry into new systems of biological production (p. 433).

There are other examples which suggest that synthetic biology is orientated temporally toward the future, again in ways that may match the molecular register (Delgado 2016). In this last part of our argument, however, we want to explain how synthetic biology, far from escaping the past, combines and mobilises diverse temporal registers, to both create value and invite political trouble.

The most renowned example of synthetic biology at work is the transformation of a yeast so as to produce a chemical precursor to artemisinic acid, an effective antimalarial drug that is usually extracted from the plant Artemisia annua. Once we are alerted to the operation of temporal registers, a survey of the ways in which this enterprise is explained reveals quite readily how shifts between historical, phyletic, and molecular registers serve to establish its value.

Introductions to the enterprise open by informing us that "[the world is] greatly indebted to Chinese scientists and traditional healers for their discovery and open sharing of the antimalarial properties of [Artemisia annua] ..." (Hale et al. 2007, p. 198). These acknowledgments then shift from the long history of use to discussions of current, agricultural methods of extracting artemisinin: 
Artemisinin ... is currently extracted from dried leaves and inflorescences from Artemisia annua, an annual herb that is primarily cultivated throughout China and Southeast Asia. Artemisia annua is a very labor-intensive crop with a lengthy growing cycle; the period from time of planting to artemisinin extraction is $12-18$ months. In addition, the plant's artemisinin content is quite sensitive to genetic backgrounds, cultivation conditions, and harvesting periods.... [It is] clear that there is a need for an additional source of artemisinin that is consistent, reliable, pure, and inexpensive ... (Hale et al. 2007, p. 199).

Having framed the plant in phyletic terms, then comes the molecular move, away from the temporalities of history and nature. Diverse and unreliable plants, as well as the associated, labor-intensive farming practices, are to be replaced with yeasts reconstructed to carry the genes required to produce the desired precursor and then grown in vats operated by a small number of highly skilled technicians. One notable advocate of synthetic biology describes the operation in the following terms:

[W] hen the project began, gene sequences for artemisinin pathway components in wormwood were available electronically, but a key gene was not available as physical DNA. Therefore, [the] team resorted to adopting a version of that gene from another plant, which they identified within a sequence database. The gene was synthesized from scratch and optimized for expression in yeast... (Carlson 2010, p. 100).

As Frow would observe, this is part of a much broader view amongst synthetic biologists that their organisms escape the hold of history and nature because the components come from anywhere, including automated synthesizers. These organisms are the fruit of human creativity. At the same time, our analysis helps to articulate how this enterprise comes to be understood as valuable through its drawing connections between diverse temporal registers. Were it not for the long history of the plant, which matters not a jot for the effectiveness of the chemical, and for the conditions in which the species is to this day maintained and farmed, which matter for reasons above and beyond the effectiveness of the chemical, the value of recombinant yeast in vats would be considerably smaller.

Importantly, this example also illustrates how and why it matters that these registers are not just semiotic, but also material assemblages. When the advocates of synthetically produced artemisinin sought to clarify the importance of their work by referring to the farmers currently cultivating Artemisia, the fact that not one, but three material and semiotic assemblages were in play quickly came to the fore. Many, in particular the Action Group on Erosion, Technology and Concentration (ETC Group), a renowned civil society organisation broadly interested in biotechnology and invested particularly in the preservation of cultural diversity and the promotion of environmentally sustainable economies, rushed to the defense of farmers whose livelihood was now threatened (ETC Group 2014). Just as with the Norfolk Horn, the field is agonistic and the ensuing debate has revolved around which organism is most important and for whom. As Griesemer has argued in another context, concerning the location of the biological level at which reproduction occurs: 
Because Darwinian evolutionary theory is framed in terms of a requirement for a capacity or disposition of heritability it leaves open questions of which inheritance mechanisms are involved in different instances. Because molecular biology is concerned with mechanisms that frequently or generally operate in gene regulation and development (though not without interest in variation), it leaves open questions of which mechanisms are significant in evolution and in what ways. Evolutionary biology is concerned with both the distribution of traits (including the presence of mechanisms) among taxa and the dynamical role of mechanisms in evolutionary processes of change within and among lineages. Thus, in asking questions about reductionism and relative significance of epigenetic phenomena in relation to well-established theories of genetic information we have to ask, "reduction for whose purpose(s)?" and "significance relative to whose problems?" (Griesemer 2011, p. 38).

Such plurality is likewise a political issue, one that is easier to map by recognizing the centrality of care. Indeed, the relationships we have described between the temporal registers and their correlate notions of worth are most illuminating if understood as pivoting around alternative notions of care (Haraway 2008; Shukin 2009). The historical register involves caring for organisms that made the world we inhabit, but are now lost to us. Care is equally important in the phyletic register, but here it is the attention and skill devoted to channelling the fecundity of the organism and converting it into new and desirable commodities, and their maintenance. The molecular register, on the other hand, evacuates care for the organism beyond investment in matching design and future effects. This said, just as we have emphasised that there may be many other temporal registers outside of the three highlighted here, there may also be many other forms of care that go into the making of synthetic biology. ${ }^{10}$

\section{Conclusion}

We have argued that the making of organisms involves multiple temporal registers. We have also characterized the material and semiotic assemblages sustaining three such registers and how they are knotted together in the process of creating value. We close with three broader conclusions about this exploration of the relationship between life, time, and the organism.

The future-orientated, promissory economy of biotechnological enterprises has been crucially important to the emergence of the sociology of expectations as subfield of sociological inquiry, but this literature has sometimes overlooked how this economy is indebted to the interplay of competing, yet mutually dependent regimes (see Brown et al. 2000; also Moreira and Palladino 2005). Our argument about the multiplicity and interplay of temporal registers not only restates the importance of

\footnotetext{
10 At the cost of pressing the parallels between synthetic biology and Deleuzian perspectives on life, time, and the organism beyond reasonable limits, it might be useful to consider how an alternative understanding of care might be constructed out of responses to Haraway's criticism that Deleuzian perspectives on non-human animals convey little care for "real" animals (Beaulieu 2011).
} 
such complexity, but also emphasises how social and cultural analysis of contemporary biology should presume neither historical, phyletic, nor molecular temporalities. Anywhere that we find material and semiotic assemblages they will be bound up with a temporal component, one that historians should seek out and empower.

The second conclusion speaks to wider debates about the creation of value in that collection of industries sometimes labelled the "bioeconomy"; see (Rajan 2006; Rose 2007; Cooper 2008; Birch and Tyfield 2013). Time, we have argued, is involved centrally in the creation of value, so much so that we might even think of the bioeconomy as produced not by freeing life from the hold of time, but by reconfiguring relations between life, time, and the organism. The same can be said of closely related enterprises to which certain organizations in our story, such as the Zoological Society of London, were early contributors, as they began to collect representatives of organisms for the purposes of their preservation for future generations, efforts that eventually came to be understood as securing "biodiversity." Might we not likewise conclude that biodiversity is made by reconfiguring these pivotal relations between life, time, and the organism? (van Dooren 2014). We offer these two suggestions as ways to immediately identify how the notion of multiple temporal registers can motivate work on issues of considerable importance today.

Our third and final conclusion concerns the organism and its relationship to the contemporary politics of "life itself" (Rose 2007). We hope to have provided a compelling description of much that occurs when people talk about the geneticization and molecularization of life. Rather than focusing on scientific discourse, the reorganization of scientific institutions, or the transformation of the marketplace, our account has highlighted how the organism is configured within different material and semiotic assemblages. Any of these approaches can of course prove revealing, but the changing configuration of the organism must remain central to any meaningful history of the present, the task of genealogy. Some will argue that our focus on the organism risks ignoring the novelty of recent interventions which have left the organism behind. Rather than asserting the primacy of one temporality over any other, our approach turns the proverbial tables upon claims to novelty, allowing us to see how they are involved in the construction of one among a number of different temporal registers, each dependent on the others. What this reaffirms is the centrality of relations between life, time, and the organism, each of which only becomes intelligible in relation to the others. Our conclusions then are made for the present, and historical research in an unreflexive mode would undo parts of our argument. The only reason that we hesitated earlier, pausing before joining Lynch's call to ontography, was to first have some greater clarity about how time works within historiographical practice. ${ }^{11}$ Nevertheless with the notion of temporal registers as a guide, and an appreciation for their ubiquity in the hands of widely divergent persons, be they venture capitalists, historians, philosophers, or sociologists, we can make the past less a rhetorical device and more an essential analytical resource for

\footnotetext{
11 The complicated relationship between ethnographic and historical modes of inquiry is discussed usefully in Ingold (2011). Like Crang, Ingold seeks to articulate a response by turning to Deleuze and Henri Bergson.
} 
any understanding of the contemporary reconfigurations of the organism and the evolving politics of life itself.

Acknowledgements Palladino was funded by the European Union's Horizon 2020 research and innovation programme, under a Marie Sklodowska-Curie Individual Fellowship (657750). Berry was funded by the European Research Council through a Consolidator Grant (616510-ENLIFE). We are grateful to Jane Calvert, Annalisa Colombino, Pablo Schyfter, Deborah Scott, and Rob Smith for their comments on an earlier draft of the paper, and to the organisers of the Research Colloquium on History and Theory of International Relations at the University of Groningen for their own, equally thoughtful, response. We also wish to acknowledge the excellent feedback and comments we received from our anonymous reviewers, both here at the Journal of the History of Biology and on an earlier draft submitted to BioSocieties.

Open Access This article is distributed under the terms of the Creative Commons Attribution 4.0 International License (http://creativecommons.org/licenses/by/4.0/), which permits unrestricted use, distribution, and reproduction in any medium, provided you give appropriate credit to the original author(s) and the source, provide a link to the Creative Commons license, and indicate if changes were made.

\section{References}

Alderson, Lawrence. 1982. Breeding Up Programmes. Ark December: 451-453.

Alderson, G.L.H., and Valerie Porter. 1994. Saving the Breeds: A History of the Rare Breeds Survival Trust. Mountfield: Pica Press.

Ark. 1976. Forum: February's question. Ark February: 54-55.

Ark. 1984. The Last of the Norfolk Horn Sheep. Ark December: 398-400.

Balmer, Andrew S., Katie Bulpin, and Susan Molyneux-Hodgson. 2014. Synthetic Biology: A Sociology of Changing Practices. Basingstoke: Palgrave Macmillan.

Beaulieu, Alain. 2011. The Status of Animality in Deleuze's Thought. Journal for Critical Animal Studies $9(1 / 2)$ : 69-88.

Berry, Dominic. 2014a. The Plant Breeding Industry after Pure Line Theory: Lessons from the National Institute of Agricultural Botany. Studies in History and Philosophy of Biology \& Biomedical Sciences 48: 25-37.

Berry, Dominic. 2014b. Bruno to Brünn; or the Pasteurization of Mendelian Genetics. Studies in History and Philosophy of Biology \& Biomedical Sciences 48: 280-286.

Birch, Kean, and David Tyfield. 2013. Theorizing the Bioeconomy: Biovalue, Biocapital, Bioeconomics... or What? Science, Technology \& Human Values 38 (3): 299-327.

Boltanski, Luc, and Laurent Thévenot. 2006. On Justification: Economies of Worth. Princeton: Princeton University Press.

Brown, Steven D. 2002. Michel Serres: Science, Translation and the Logic of the Parasite. Theory, Culture \& Society 19 (3): 1-27.

Brown, Nik, Brian Rappert, and Andrew Webster. 2000. Contested Futures: A Sociology of Prospective Techno-Science. Aldershot: Ashgate.

Buchanan, Brett. 2008. Onto-Ethologies: The Animal Environments of Uexküll, Heidegger, MerleauPonty, and Deleuze. Albany: State University of New York Press.

Campos, Luis. 2010. That Was the Synthetic Biology That Was. In Synthetic Biology: The Technoscience and Its Societal Consequences, ed. Markus Schmidt, Alexander Kelle, Agomoni Ganguli-Mitra, and Huib de Vriend, 5-21. New York: Springer.

Carlson, Robert H. 2010. Biology is Technology: The Promise, Peril, and New Business of Engineering Life. Cambridge: Harvard University Press.

Church, George, and Ed Regis. 2012. Regenesis: How Synthetic Biology will Reinvent Nature and Ourselves. New York: Basic Books.

Clarke, Adele E., and Joan Fujimura. 1992. What Tools? Which Jobs? Why right? In The Right Tools for the Job: At Work in Twentieth-Century Life Sciences, ed. Adele E. Clarke and Joan Fujimura, 3-44. Princeton: Princeton University Press. 
Colebrook, Claire. 2011. Time and Autopoiesis: The Organism has no Future. In Deleuze and the Body, ed. Laura Guillaume and Joe Hughes, 9-28. Edinburgh: Edinburgh University Press.

Colombino, Annalisa, and Paolo Giaccaria. 2015. Breed Contra Beef: The Making of Piedmontese Cattle. In Political Ecologies of Meat, ed. Jody Emel and Harvey Neo, 161-177. New York: Routledge.

Colombino, Annalisa, and Paolo Giaccaria. 2016. Dead Liveness/Living Deadness: Thresholds of NonHuman Life and Death in Biocapitalism. Environment and Planning D 34 (6): 1044-1062.

Cooper, Melinda E. 2008. Life as Surplus: Biotechnology and Capitalism in the Neoliberal Era. Seattle: University of Washington Press.

Culley, George. 1786. Observations on Livestock. London: Robinson.

Crang, Mike. 2001. Rhythms of the City: Temporalised Space and Motion. In Timespace: Geographies of Temporality, ed. Jon May and Nigel Thrift, 187-207. London: Routledge.

Dean, Mitchell. 1994. Critical and Effective Histories: Foucault's Methods and Historical Sociology. London: Routledge.

Deleuze, Gilles. 2004. Difference and Repetition. London: Continuum.

Deleuze, Gilles, and Guattari Félix. 1988. A Thousand Plateaus: Capitalism \& Schizophrenia. London: Continuum.

Delgado, Ana. 2016. Assembling Desires: Synthetic Biology and the Wish to Act at a Distant Time. Environment and Planning D: Society and Space 34 (5): 914-934.

Dussauge, Isabelle, Claes-Fredrik Helgesson, Francis Lee, and Steve Woolgar. 2015. On the Omnipresence, Diversity, and Elusiveness of Values in the Life Sciences and Medicine. In Value Practices in the Life Sciences and Medicine, ed. Isabelle Dussauge, Claes-Fredrik Helgesson, and Francis Lee, 1-29. New York: Oxford University Press.

Dymond, Alastair. 1982. Update on the Norfolk Horn. Ark January: 6-8.

ETC Group. 2013. A Mammoth Distraction: Syn-Bio and 'De-Extinction'. etcgroup.org. http://www. etcgroup.org/content/mammoth-distraction-syn-bio-and-de-extinction. Accessed 12 April 2017.

ETC Group. 2014. Artemisinin \& Synthetic Biology: A Case Study. etcgroup.org. http://www.etcgr oup.org/sites/www.etcgroup.org/files/ETC-artemisinin-synbio-casestudy2014.pdf. Accessed 10 January 2017.

Endy, Drew. 2014. Nature is Designed. In Synthetic Aesthetics: Investigating Synthetic Biology's Designs on Nature, ed. Alexandra Daisy Ginsberg, Jane Calvert, Pablo Schyfter, Alistair Elfick, and Drew Endy, 73-85. Cambridge: MIT Press.

Evans, Nicholas, and Richard Yarwood. 2000. The Politicization of Livestock: Rare Breeds and Countryside Conservation. Sociologia Ruralis 40 (2): 228-248.

Foucault, Michel. 1977. Nietzsche, Genealogy, History. In Language, Counter-Memory, Practice: Selected Essays and Interviews by Michel Foucault, ed. Donal F. Bouchard, 139-164. Ithaca: Cornell University Press.

Fox-Keller, Evelyn. 2009. What does Synthetic Biology have to do with Biology? BioSocieties 4 (2): 291-302.

Franklin, Sarah. 2007. Dolly Mixtures: The Remaking of Genealogy. Durham: Duke University Press.

Frow, Emma K. 2013. Making Big Promises Come True Articulating and Realizing Value in Synthetic Biology. BioSocieties 8 (4): 432-448.

Griesemer, James R. 2011. Heuristic Reductionism and the Relative Significance of Epigenetic Inheritance in Evolution. In Linking Genotype and Phenotype in Development and Evolution, ed. Benedikt Hallgrímsson and Brian K. Hall, 14-40. Berkeley: University of California Press.

Ginsberg, Alexandra Daisy, Jane Calvert, Pablo Schyfter, Alistair Elfick, and Drew Endy. 2014. Synthetic Aesthetics: Investigating Synthetic Biology's Designs on Nature. Cambridge, MA: The MIT Press.

Guggenheim, Michael, and Jörg Potthast. 2012. Symmetrical Twins: On the Relationship between Actor-network Theory and the Sociology of Critical Capacities. European Journal of Social Theory 15: 157-178.

Hale, Victoria, Jay D. Keasling, Neil Renninger, and Thierry T. Diaganna. 2007. Microbially Derived Artemisinin: A Biotechnology Solution to the Global Problem of Access to Affordable Antimalarial Drugs. American Journal of Tropical Medicine and Hygiene 77: 198-202.

Haraway, Donna J. 2008. When Species Meet. Minneapolis: University of Minnesota Press.

Holloway, Lewis, and Carol Morris. 2012. Contesting Genetic Knowledge-Practices in Livestock Breeding: Biopower, Biosocial Collectivities, and Heterogeneous Resistances. Environment and Planning D: Society and Space 30 (1): 60-77. 
Hoy, David Couzens. 2008. Genealogy, Phenomenology, Critical Theory. Journal of the Philosophy of History 2 (3): 276-294.

Ingold, Tim. 2011. Being Alive: Essays on Movement, Knowledge and Description. London: Routledge.

Jewell, Peter A. 1993. Foreword. In Black Faces: A History of East Anglian Sheep Breeds, ed. WadeMartins Peter, xiv-xv. Norwich: Norfolk Museums Service.

Jewell, Peter A. 1975. The Case for the Preservation of Rare Breeds of Domestic Livestock. Ark April: 84-88.

Johnson, Elizabeth. 2010. Reinventing Biological Life, Reinventing 'the Human'. Ephemera 10 (2): 177-193.

Latour, Bruno. 1986. Visualization and Cognition: Thinking with Eyes and Hands. In Knowledge and Society: Studies in the Sociology of Culture Past and Present, ed. Elizabeth Long and Henrika Kuklick, 1-40. Greenwich: JAI Press.

Law, John. 1986. Laboratories and Texts. In Mapping the Dynamics of Science and Technology, ed. Michel Callon, Arie Rip, and John Law, 35-50. London: Macmillan.

Law, John. 2004. After Method: Mess in Social Science Research. London: Routledge.

Lowenthal, David. 2005. Natural and Cultural Heritage. International Journal of Heritage Studies 11 (1): 81-92.

Lowenthal, David. 1998. The Heritage Crusade and the Spoils of History. Cambridge: Cambridge University Press.

Lynch, Michael. 2013. Ontography: Investigating the Production of Things, Deflating Ontology. Social Studies of Science 43 (3): 444-462.

Marks, John. 2006. Molecular Biology in the Work of Deleuze and Guattari. Paragraph 29: 81-97.

Mol, Annemarie. 2002. The Body Multiple: Ontology in Medical Practice. Durham: Duke University Press.

Moreira, Tiago, and Paolo Palladino. 2005. Between Truth and Hope: On Parkinson's Disease, Neurotransplantation and the Production of the 'Self'. History of the Human Sciences 18: 55-82.

NHBG. 2012. Breed History. http://www.norfolkhornsheep.co.uk/breed-history/. Accessed 10 January 2017.

Overton, Mark. 1996. Re-Establishing the English Agricultural Revolution. Agricultural History Review 44 (1): 1-20.

Palladino, Paolo. 2003. Plants, Patients and the Historian: On (Re)membering in the Age Genetic Engineering. New Brunswick: Rutgers University Press.

Protevi, John. 2012. Deleuze and Life. In The Cambridge Companion to Deleuze, ed. Daniel W. Smith and Henry Somers-Hall, 239-264. Cambridge: Cambridge University Press.

Rajan, Kaushik Sunder. 2006. Biocapital: The Constitution of Postgenomic Life. Durham: Duke University Press.

Rayns, Frank. 1975. Norfolk Horn Sheep. Ark December: 318-324.

Ritvo, Harriet. 1987. The Animal Estate: The English and Other Creatures in the Victorian Age. Cambridge, MA: Harvard University Press.

Rose, Nikolas. 2007. The Politics of Life Itself: Biomedicine, Power, and Subjectivity in the TwentyFirst Century. Princeton: Princeton University Press.

Scott, Deborah, Dominic Berry, and Jane Calvert. 2018. Synthetic biology. In Handbook of Genomics, Health and Society, ed. Sahra Gibbon, Barbara Prainsack, Stephen Hilgartner, and Janelle Lamoreaux, 300-307. London: Routledge.

Serres, Michel. 2007. The Parasite. Minneapolis: University of Minnesota Press.

Shavit, Ayelet, and James Griesemer. 2009. There and Back Again, or the Problem of Locality in Biodiversity Surveys. Philosophy of Science 76: 273-294.

Sheppy, Andrew J. 1976. Off with the New. Ark February: 117.

Sheppy, Andrew J. 1979. Outcrossing as a Breeding Policy. Ark December: 380-386.

Shukin, Nicole. 2009. Animal Capital: Rendering Life in Biopolitical Times. Minneapolis: University of Minnesota Press.

Storey, David E. 2015. Naturalizing Heidegger: His Confrontation with Nietzsche, His Contributions to Environmental Philosophy. Albany: State University of New York Press.

Strathern, Marilyn. 1992. After Nature: English Kinship in the Late Twentieth Century. Cambridge: Cambridge University Press.

van Dooren, Thom. 2014. Flight Ways: Life and Loss at the Edge of Extinction. New York: Columbia University Press. 
van Heur, Bas, Loet Leydesdorff, and Sally Wyatt. 2012. Turning to Ontology in STS? Turning to STS Through 'Ontology'. Social Studies of Science 43: 341-362.

Wade-Martins, Peter. 1993. Black Faces: A History of East Anglian Sheep Breeds. Norwich: Norfolk Museums Service.

Walling, Philip. 2014. Counting Sheep: A Celebration of the Pastoral Heritage of Britain. London: Profile Books.

Woods, Rebecca J.H. 2013. The Herds Shot Round the World: Native Breeds and the British Empire, 1800-1900. Ph.D. Thesis, Program in Science, Technology, and Society, Massachusetts Institute of Technology, Cambridge, MA.

Woods, Rebecca J.H. 2017. The Herds Shot Round the World: Native Breeds and the British Empire, 1800-1900. Chapel Hill: University of North Carolina Press.

Yarwood, Richard, and Nick Evans. 2006. A Lleyn Sweep for Local Sheep? Breed Societies and the Geographies of Welsh Livestock. Environment and Planning A 38 (7): 1307-1326. 